\title{
Olivine in the Udachnaya-East kimberlite (Yakutia, Russia): morphology, compositional zoning and origin
}

\author{
Maya B. Kamenetsky ${ }^{1}$, Vadim S. Kamenetsky ${ }^{1}$, Alexander V. Sobolev ${ }^{2}$, Alexander V. \\ Golovin $^{3}$, Victor V. Sharygin ${ }^{3}$, Sylvie Demouchy ${ }^{4}$, Kevin Faure ${ }^{5}$ and Dmitry V. Kuzmin ${ }^{3}$ \\ ${ }^{1}$ CODES and School of Earth Sciences, University of Tasmania, Hobart, TAS, Australia \\ ${ }^{2}$ Vernadsky Institute of Geochemistry, Moscow, Russia \\ ${ }^{3}$ Institute of Geology and Mineralogy, Novosibirsk, Russia \\ ${ }^{4}$ Department of Geology and Geophysics, University of Minnesota, Minneapolis, USA \\ ${ }^{5}$ National Isotope Centre, GNS Science, Lower Hutt, New Zealand
}

Olivine is the principal mineral of kimberlite magmas, and is the main contributor to the high-Mg ultramafic composition of kimberlite rocks. Enrichment in olivine component, even in so-called aphanitic kimberlites, presents a problem in matching whole rock kimberlite compositions to experimental melts at peridotite or eclogite solidus. It has been long recognised that a large portion of olivine in kimberlites was not liquidus, i.e. xenogenic. Unfortunately, the masking effects of alteration, common in kimberlites, do not permit routine recognition of olivine generations, and so the olivine component originally dissolved in the kimberlite parental melt remains controversial. The disguising effects of alteration, common in group-I kimberlites, are overcome in our study of uniquely preserved diamondiferous kimberlites of the Udachnaya-East pipe (Yakutia, northern Siberia). These serpentine-free, but nevertheless ultramafic, kimberlites from deep levels of the pipe contain large amount of olivine ( $50 \mathrm{vol} \%$ ) in a chloride-carbonate groundmass (Fig. 1; Kamenetsky et al., 2004; Kamenetsky et al., 2007b). Several thousand olivine grains from three hypabyssal kimberlites were handpicked, mounted in epoxy, ground and analysed at midplane surfaces (Kamenetsky et al., 2008).

Olivine is represented by two populations (olivine-I and groundmass olivine-II) differing in morphology, colour and grain size, and mineral and melt inclusions trapped in different zones (Fig. 2-4). The large fragmental olivine-I (also used terms macrocrysts and xenocrysts) is variable in terms of major $\left(\mathrm{Fo}_{85-94}\right.$, although most grains are Fo $>91$ ) and trace element concentrations (e.g., 0.15-0.40 wt\% NiO; 0-0.06 wt\% $\mathrm{CaO}$; 0.06-0.18 wt\% MnO) (Fig. 2A), including $\mathrm{H}_{2} \mathrm{O}$ content (10-136 ppm).

The groundmass olivine-II is recognised by smaller grain sizes and perfect crystallographic tablet shapes that indicate crystallisation from or re-equilibration with a melt (Fig. 2B, 3, 4). However, crystallisation history of olivine-II is not alike that of olivine in other picrites, as indicated by complex zoning in terms of Fo

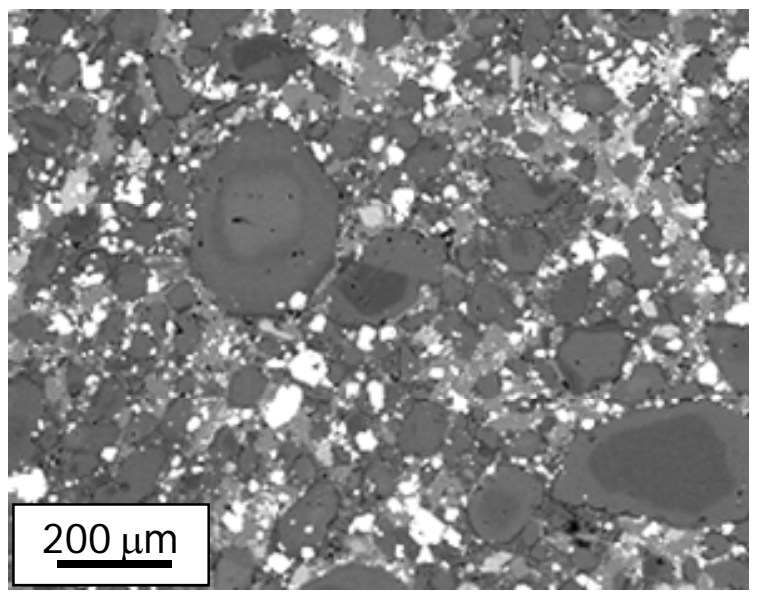

Fig. 1. BSE image of the Udachnaya-East kimberlite showing the shape, size and 'zoning'patterns of olivine grains, and matrix composed of carbonates, chlorides and oxides.

and trace element contents (Fig. 2-4). The cores of olivine-II are extremely variable in shapes (from ideally faceted to amoeba-like), and compositionally similar to olivine-I. Similar compositions and inclusions of Cr-diopside in olivine-I and cores of olivine-II imply a genetic link between these two types of olivine, and their origin from multiple sources in the mantle and lithosphere.

The volumetrically significant rims of olivine-II (at least 50 vol\%) have constant Fo values (89.0 \pm 0.2 mol\%), but variable trace element compositions (e.g., 0.15-0.33 wt\% NiO; 0.02-0.12 wt\% CaO; 0.11-0.20 wt\% $\mathrm{MnO}$ ) (Fig. 2B). Their origin from the melt is supported by presence of entrapped inclusions of the carbonate-chloride melt (Fig. 4) and minerals (Crspinel, perovskite, rutile and phlogopite). Same assemblage represents the Udachnaya-East kimberlite groundmass (Fig. 1).

Olivine-I and olivine-II have oxygen isotope values $(+5.6 \pm 0.1 \%$ VSMOW $)$ that are indistinguishable from one another, but higher than values in "typical" 
mantle olivine $(+5.18 \pm 0.28 \%$ o). These elevated values likely reflect a ${ }^{18} \mathrm{O}$ - enriched source (e.g., recycled oceanic crust) and equilibrium with the UdachnayaEast carbonate-enriched melt $(+12 \%)$ at low temperatures (i.e. $\quad<700-750^{\circ} \mathrm{C}$, based on homogenisation temperatures of melt inclusions; Kamenetsky et al., 2004).
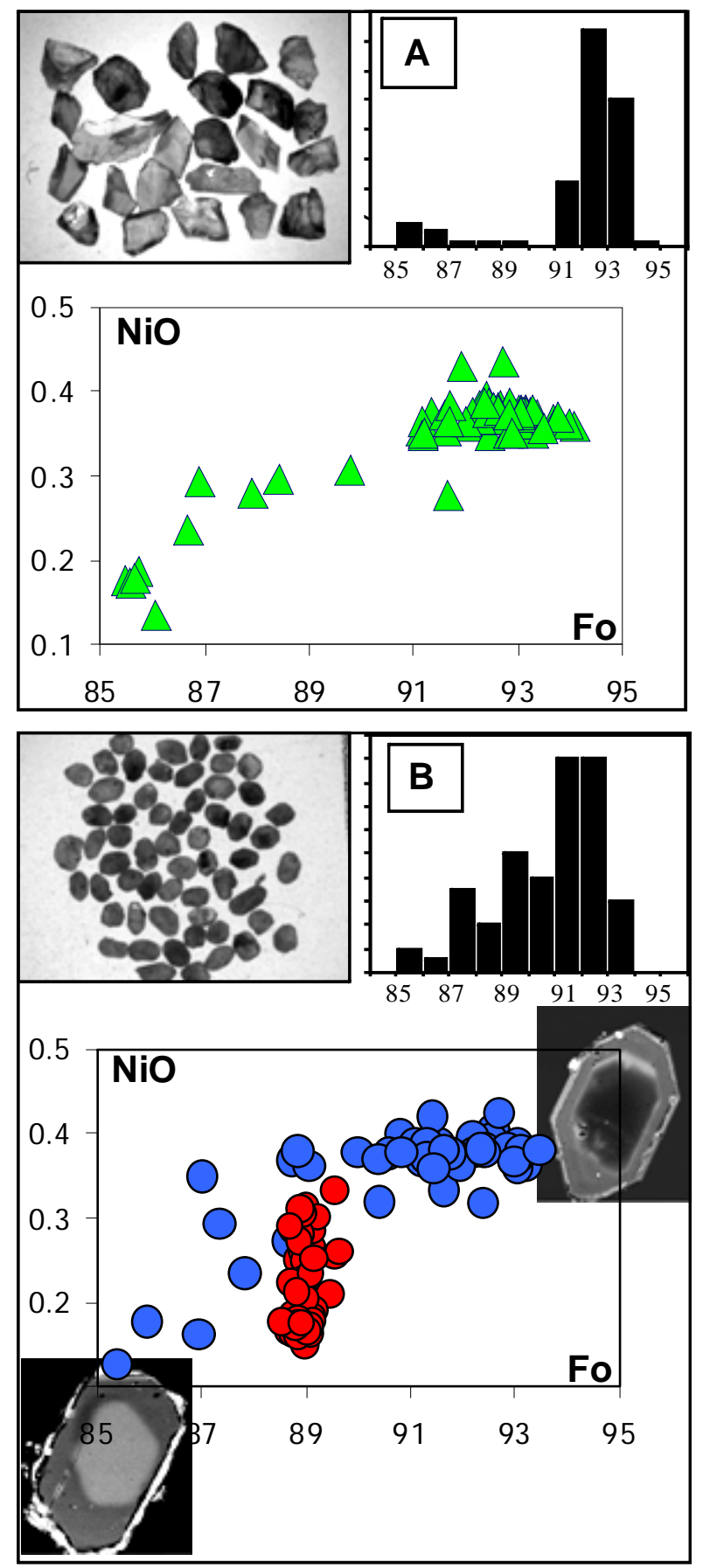

Fig.2. Images and compositions of two main generations of olivine in the Udachnaya-East kimberlite; (A) - macrocrysts/xenocrysts; (B) groundmass phenocrysts. Note two contrasting types of “zoning” in the BSE images of olivine-II.

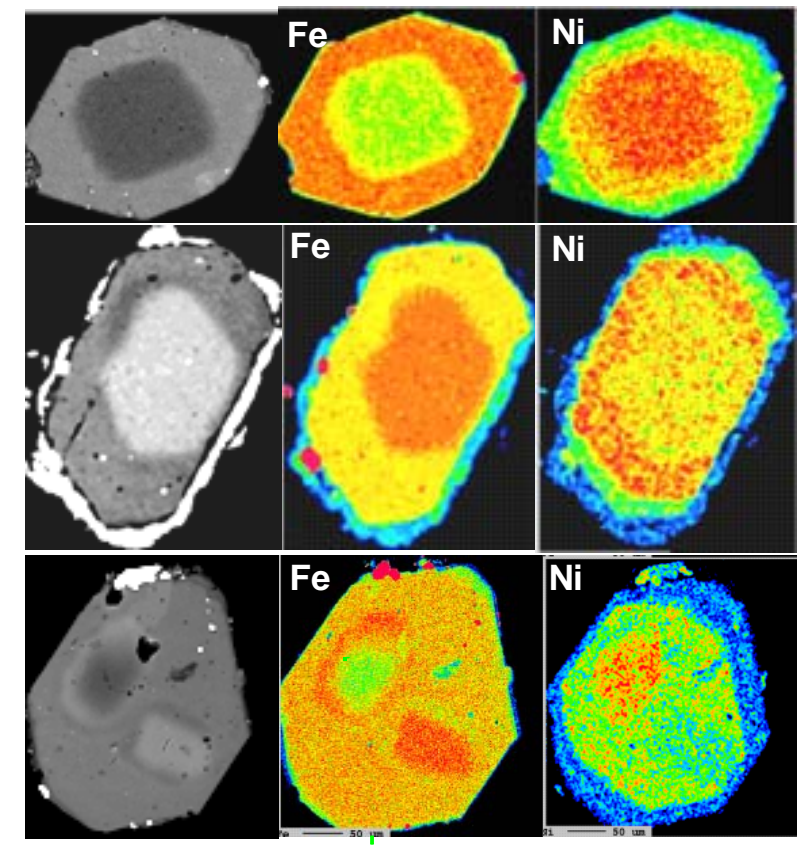

Fig.3. BSE images and X-ray element maps of groundmass olivine showing complex interplay between $\mathrm{Fe}(1 / \mathrm{Fo})$ and $\mathrm{Ni}$ contents in olivine grains with different zoning pattern (normal, reverse zoning and grain with two contrasting cores)

Modelling of multiple origins of olivine in kimberlite melts and kimberlite rocks should take into account the important fact that olivine in the Udachnaya-East kimberlite share the same morphological, structural and compositional features with olivine from kimberlites across the world (Boyd and Clement, 1977; Fedortchouk and Canil, 2004; Mitchell, 1973; Moore, 1988; Nielsen and Jensen, 2005). The common features of kimberlitic olivine include presence of at least two olivine populations, similar compositions of macrocrysts and cores of groundmass olivine, and a limited range of Fo content in the groundmass olivineII rims, but variable trace element abundances. Significant diversity of the groundmass olivine-II cores in shape, size and composition (Fig. 2-4) suggests different evolutionary paths for individual grains, related to growth, recrystallisation, transport, dissolution and re-growth in different mantle-melt and crust-melt environments. The cores with smoothed crystallographic shapes were likely to have precursors as individual olivine grains (alike macrocrysts) that experienced abrasion during upward transport at extremely high speeds, expected of buoyant kimberlite magma. The uniform Fo compositions of the rims are enigmatic (Fig. 2B), given the rims represent significant part of the population (Fig. 3, 4). A possible answer is that the melt's $\mathrm{Fe}^{2+} / \mathrm{Mg}$ is buffered, which can occur if the coefficient $(\mathrm{Kd})$ of $\mathrm{Mg}-\mathrm{Fe}$ distribution between olivine and a kimberlite melt is significantly higher than for common basaltic systems. Such high Kd values ( $>0.5$ ) have been recorded in experiments with Ca-Mg carbonatitic liquids (Dalton and Wood, 1993; Girnis et al., 2005), and they can be even higher for an alkali-rich carbonatitic melt. 


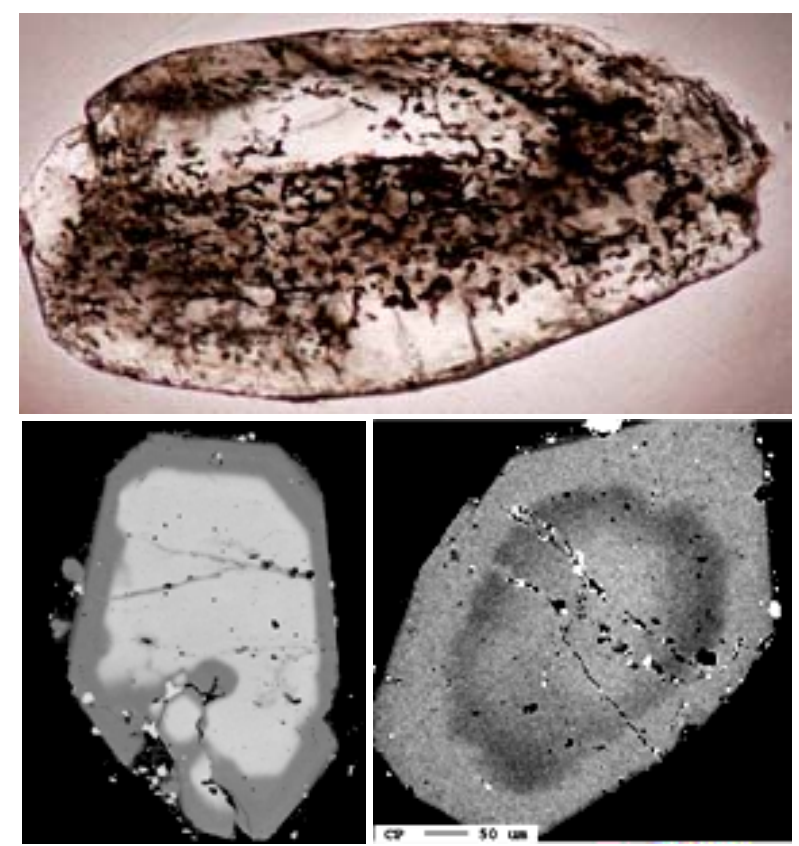

Fig.4. Distribution of melt inclusions along healed fractures in cores of the groundmass olivine-II.

Our study of the olivine populations and complex zoning of the groundmass olivine in the UdachnayaEast kimberlite provides evidence that olivine crystals were first entrapped by a protokimberlite melt at depth, then partly abraded, dissolved and re-crystallised on ascent, and finally regenerated during emplacement. We suggest that the history of kimberlitic olivine is owed to the extraordinary melt composition (Kamenetsky et al., 2004; Kamenetsky et al., 2007a; Kamenetsky et al., 2007b; Maas et al., 2005), as well as conditions during melt generation, transport and emplacement. The kimberlite melt is argued to have originated as a chloride-carbonate liquid with chemical and physical properties consistent with inferred small melting degrees in the presence of garnet and inferred ultra-fast ascent (very low viscosity and density and high buoyancy). We envisage such liquids to be poor in "ultramafic" or "basaltic" aluminosilicate components, and likely undersaturated in olivine (especially if the source is eclogite). The ascending liquids became olivine-laden and olivine-saturated by scavenging olivine crystals from the pathway/country rocks and dissolving them en route to the surface. During emplacement the kimberlite magma changed progressively towards an original alkali-rich chloridecarbonate melt by extensively crystallising groundmass olivine and gravitational separation of olivine macrocrysts and phenocrysts in the pipe.

\section{References}

Boyd, F.R. and Clement, C.R., 1977. Compositional zoning of olivines in kimberlites from the De Beers mine, Kimberley, South Africa. Carnegie Institution of Washington Yearbook, 76: 485-493.

Dalton, J.A. and Wood, B.J., 1993. The partitioning of Fe and Mg between olivine and carbonate and the stability of carbonate under mantle conditions. Contributions to Mineralogy and Petrology, 114: 501-509.

Fedortchouk, Y. and Canil, D., 2004. Intensive variables in kimberlite magmas, Lac de Gras, Canada and implications for diamond survival. Journal of Petrology, 45: 1725-1745.

Girnis, A.V., Bulatov, V.K. and Brey, G.P., 2005. Transition from kimberlite to carbonatite melt under mantle parameters: An experimental study. Petrology, 13: $1-15$.

Kamenetsky, M.B. et al., 2004a. Kimberlite melts rich in alkali chlorides and carbonates: a potent metasomatic agent in the mantle. Geology, 32: 845848.

Kamenetsky, V.S., Kamenetsky, M.B., Sharygin, V.V., Faure, K. and Golovin, A.V., 2007a. Chloride and carbonate immiscible liquids at the closure of the kimberlite magma evolution (Udachnaya-East kimberlite, Siberia). Chemical Geology, 237: 384400.

Kamenetsky, V.S., Kamenetsky, M.B., Sharygin, V.V. and Golovin, A.V., 2007b. Carbonate-chloride enrichment in fresh kimberlites of the UdachnayaEast pipe, Siberia: A clue to physical properties of kimberlite magmas? Geophysical Research Letters, 34: L09316, doi:10.1029/2007GL029389.

Kamenetsky, V.S. et al., 2008. Olivine in the Udachnaya-East kimberlite (Yakutia, Russia): types, compositions and origins. Journal of Petrology, 49: 823-839.

Maas, R., Kamenetsky, M.B., Sobolev, A.V., Kamenetsky, V.S. and Sobolev, N.V., 2005. Sr, Nd, and Pb isotope evidence for a mantle origin of alkali chlorides and carbonates in the Udachnaya kimberlite, Siberia. Geology, 33: 549-552.

Mitchell, R.H., 1973. Composition of olivine, silica activity and oxygen fugacity in kimberlite. Lithos, 6: 65-81.

Moore, A.E., 1988. Olivine: a monitor of magma evolutionary paths in kimberlites and olivine melilitites. Contributions to Mineralogy and Petrology, 99: 238-248.

Nielsen, T.F.D. and Jensen, S.M., 2005. The Majuagaa calcite-kimberlite dyke, Maniitsoq, southern West Greenland, Geological Survey of Denmark and Greenland, Report 2005/43. 